\title{
Effect of Corporate Governance on Microfinance Institutions Financial Performance in Ethiopia
}

\author{
Berhanu Urgessa \\ Chief Operation Officer, Addis Credit and Saving Institution S.C \\ Addis Ababa, Ethiopia \\ Adane Atara $(\mathrm{PhD})$ \\ School of Commerce, Addis Ababa University \\ Addis Ababa, Ethiopia
}

\begin{abstract}
The microfinance sector in Ethiopia is not yet proved to be a profitable business that attracts commercial investors. Most of the shareholders of the MFIs are regional governments, associations and NGO's. Recently directive has been issued, which allow MFIs to transform to banks that give MFIs an opportunity to move to the trajectory of full commercialization with the argument of profit motive to be self-sustainable and address other mission. This indicates that commercialization is currently big concern of MFIs in Ethiopia. Thus, the objective of this research project was to identify the effect of corporate governance on financial performance of MFIs in Ethiopia. Explanatory research design was employed to examine the effect of corporate governance practices such as board size, board sub-committee, numeration, and competence of boards and CEO on financial performances (measured by ROA) of MFIs. From the total 34 registered members of AEMFIs, three years data of 25 MFIs taken from secondary and primary source was analyzed. The result of regression analysis reveals that out of six corporate governance variables and one control variable identified for the study, three explanatory variables have found significant effect on financial performance of MFIs in Ethiopia. Effect of board of directors (BoDs) member size, educational level of boards of BoDs, industry experience of Chief Executive Officer (CEO) on ROA is positive but not significant. Numerations for BoDs, CEO education level and MFIs Scale have positive effect on ROA and statically significant at 5\%,5\% and 1\% level. The result also reveals that the overall fixed effect regression model is significant at $1 \%$ level and adjusted $\mathrm{R}$ square is 0.504 implies that the over effect of the corporate governance variables included in the study is significant and jointly explain $50.4 \%$ of financial performance of MFIs in Ethiopia. As a result, due attention need to be given for these corporate governance practices to attain required level financial performance and insure sustainability through commercialization.
\end{abstract}

Keywords: Microfinance, corporate governance practices, financial performance, Ethiopia

DOI: $10.7176 /$ RJFA/12-13-04

Publication date:July $31^{\text {st }} 2021$

\section{INTRODUCTION}

The main challenge of MFIs remains their survival, and to meet this challenge, MFIs need to be competitive. The poor performance of MFIs is usually attributed to their decision-making and operational processes. The governance of MFIs is therefore identified as one of their main risks. Despite this, governance is still little explored in these institutions and empirical studies find a weak relationship between classical governance mechanisms and MFI performance, especially for the MFIs situated in Africa (Thrikawala et al., 2013a) as cited by Léopold D et al (2017).

In Ethiopia the provision of microfinance service has been carried out by donor funds until the first licensing and supervision of microfinance business was issued in 1996. This practice had weakened the development of commercialization of microfinance services (Belete 2015).

The current regulatory framework requires microfinance institutions to be formed as share companies (Microfinance business proclamation NO. 626/2009). However, the microfinance sector in Ethiopia is not yet proved to be a profitable business that attracts commercial investors rather than social investors. As a result, most of the shareholders of the MFIs are regional governments, associations and NGO's.

Yet these microfinance institutions have made remarkable progress over the past decades, in providing financial services for poor households (Ahma, 2012) as cited in (Asefa, 2014)

At moment, however, commercialization of microfinance with the argument of profit motive to be selfsustainable and addressing social mission would be the main area of concern. To this end, though some Ethiopian MFIs have proven to have self-sustainable position while pursuing the social objective, selfsustainability of some MFls seem to be doubtful as they are still dependent on irregular donor or government subsidies though assumed to have the same operating environment such as legal, regulatory and macroeconomic environments. Besides, the flow of private investors to the sector is very limited (Asefa, 2014).

National bank of Ethiopia (NBE) directive incorporates provisions relevant to the governance of 
microfinance institution. The directive put a minimum requirement for persons with significant influence in Microfinance Institution what the directive calls fit and proper criteria. The fit and proper criteria include education, experience and age of Board of Directors (BODs) and Chief Executive Officer (CEO) (NBE directive number $\mathrm{MFI} / 21 / 2012$ ).

Although there are few studies conducted on the effect of corporate governance performance of microfinance in Ethiopia, they have gaps in address all relevant corporate governance variables and lacks consistence in in its findings. For instance, Eyob (2016) found that board size has negative and significant relationship with financial performance of MFIs in Ethiopia whereas Belete (2015) had the opposite. Besides, NBE (2020) have issued directive that allow MFIs to transform to banks, that give MFIs an opportunity to move to the trajectory of full commercialization and at the same time providing microfinance services. This indicates that commercialization is currently big concern of MFIs in Ethiopia.

Thus, the objective of the study was to identify the effect of corporate governance on financial performance of MFIs in Ethiopia.

\section{Literature Review}

\subsection{Concept of Microfinance}

Microfinance is defined as the provision of financial services, mostly savings and credit to the poor and low income households that otherwise don't have access to conventional commercial banks (Rock et al., 1998). According to Robinson (2001) Microfinance is financial services primarily credit and savings provided to people who engaged in small scale enterprises. It was first declared as a way to unleash the productive capacities of poor people dependent on self-employment (Hulme and Mosley 1996). According to Yunus (2016), microfinance would transform customers' businesses by providing capital; that would increase borrowers' earnings and ultimately eliminate poverty. Microfinance has been feted for introducing innovations in credit contracts, particularly group lending and installment-lending. More broadly, microfinance demonstrates a new mode of development intervention, one that displaces governments as central actors and turns to marketmechanisms to deliver services through a range of institutions that integrate social and financial goals (Cull and Morduch 2017).

Importance of microfinance has been recognized worldwide not only as a tool to fight poverty but also to insure peace when Mohammed Yunus, founder of Grameen Bank in Bangladish, was granted Nobel Prize in October 2006. "Lasting peace cannot be achieved unless large population groups find ways in which to break out of poverty. Microfinance is one such means. Development from below also serves to advance democracy and human rights", were the words to announce the Prize (Leila Mokkadem 2009).

\subsection{Concept of Corporate Governance}

According to agency theory, conflict of interest between agent (manager) and principal (shareholders) could be reduced through good corporate governance. The theory argue that the agent strive to achieve his personal goals at the expense of the principal. Mangers are mostly motivated by their own personal interests and benefits, and work to maximize their own personal benefit rather than considering shareholders' interests and maximizing shareholders wealth. To reduce agency problem there must be better monitoring and controlling mechanisms which helps to ensure that managers pursue the interests of shareholders rather than only their own interests, which possible through good corporate practices (Habbash 2010).

Fama \& Jensen (1983) as cited by (Habbash 2010) argue that shareholders monitor and control managers through their representatives such as board of directors. Boards of directors are considered as an important device to protect shareholders from being exploited by managers and help to effectively control managers when they try to maximize their self-interest at the expense of the company's profitability and as consequence good corporate governance mechanisms enhance profitability. Thus, according to this argument, corporate governance mechanisms are designed to align the interest of owners and managers, constrained the opportunistic behaviors of managers and protect shareholder interests, generally to solve agency problem.

Stockholders theory in the other hand extends the narrow focus of agency theory on shareholders' interest to stakeholders to take into account the interests of many different groups and individuals, including interest groups related to social and ethical considerations. According to this theory good corporate governance helps to maximize the mutual interest of all stockholders. Moreover, corporate governance enables the firm to consider about all stockholders such as the customers, employee, shareholders, social and can create a stable environment for sustainable development (Habbash 2010).

Resource dependency theory also explained the importance of corporate governance. According to resource dependency theory, the role of board of directors is related to providing access to resources needed by the firm. The theory explained that the primary function of the board of directors is to provide resources to the firm and directors are viewed as an important resource to the firm. Directors bring resources to the firm, such as information, skills, business expertise, access to key constituents such as suppliers, buyers, public policy makers, 
social groups as well as legitimacy. The resource based approach notes that the board of directors could support the management in areas where in-firm knowledge is limited or lacking. The resource dependence model suggests that the board of directors could be used as a mechanism to form links with the external environment in order to support the management in the achievement of organizational goals (Abdullah and Valentine 2009) as cited by (Eyob 2016). Recently economists and management scholars tend to assign to boards the dual role of monitors and advisers of management. The composition of corporate boards is crucial to providing information for monitoring and counseling and to ensuring effective decision-making (Ferreira 2010).

According to Hilb (2008) corporate governance is a system by which companies are strategically directed, interactively managed and holistically controlled in an entrepreneurial and ethical way and in a manner appropriate to each particular context.

Hussien (2012) has also defined corporate governance as all issues related to ownership and control of the corporate property, the rights of shareholders and management, powers and responsibilities of the Board of Directors, disclosure and transparency of corporate information, the protection of interests of stakeholders that are not shareholders and enforcement of rights. According to this definition, corporate governance systems depend upon a set of institutions such as laws, regulations, contract enforcement and norms that create selfgoverning firms as the central element of a competitive market economy.

\subsection{Corporate Governance and Performance of MFIs}

Study was conducted by Chenuos et al (2014) to investigate the effect of corporate governance on Kenyan Microfinance institutions financial sustainability on ten MFIs taking data for the period of eleven years. The researchers were used explanatory research design and panel data analysis method to establish the causal effect relationship between corporate governance variables and the financial sustainability of the MFIs in Kenya. The study found that corporate governance characteristics such as CEO duality, board size, board composition and CEO gender have significant effect on financial sustainability of MFIs in Kenya.

Van Dang et al (2020) have also analyzed the relationship between corporate governance and financial performance of MFIs in Vietnam. The data was collected and involves 100 MFIs from Vietnam of three years from 2016 to 2018. The researchers constructed a firm-level index of corporate governance based on aspects of leadership and ownership structure. The study incorporated board size; board diversity with respect to gender, financial expertise, and local residency; CEO/chairman duality; female CEO; and shareholding ownership type. The authors examined the relationship between the governance index and measures of financial performance such as return on asset, return on equity, and operational self-sufficiency. A two-stage least squares estimation approaches was adopted with instrumental variables. Finally the researchers conclude that profitability and sustainability of MFIs improve with good governance practices and conversely that more profitable and sustainable MFIs have better governance systems.

Léopold D et al (2017) examined whether the effect of governance mechanisms on the performance of MFIs differs according to their legal status in the Cameroonian context. The researchers based their study on the current micro-finance governance literature and on data collected by a questionnaire administered to a sample of 137 of one year data of Cameroonian MFIs. After the analysis, the researchers found two main results. Firstly, at the global level, very few mechanisms of governance had a significant effect on the performance of the MFIs. Secondly, a comparative analysis showed that the implementation of differentiated governance mechanisms according to the legal status of the MFI (cooperative and mutual benefit companies, nonprofit NGOs, and private companies and profit-seeking NGOs) improves their performance. They conclude that the mechanisms that affect performance are relatively different according to the category of MFI. they further concluded base on the result that the result consolidate the idea that the analysis of the impact of the mechanisms of governance on the performance of MFIs requires not only an approach that is specific to the sector, but also an approach that is adapted to the type of ownership (legal status).

Eyob (2016) has conducted study to analyze effects of corporate governance mechanisms on the performance of Ethiopian MFIs. The researcher have selected five MFIs to analyze the effect of six corporate governance variables (board size, educational qualification of boards, audit committee size, board gender diversity, business management experience of boards and industry specific experience of boards) on performance of MFIs measured using two variables (return on asset and return on equity) by using ten years panel data. The data was analyzed by using multiple linear regression models.

The result showed that board size, gender diversity and size of audit committee have negative and significant relationship with financial performance of MFIs whereas industry specific experience and educational qualification of the board have positive relationship. The study also found that the effect of business management experience of directors on performance is inconclusive.

In 2015 has also analyzed the impact of corporate governance on performance of MFIs in Ethiopia. The researcher collected seven years data from ten MFIs to analyze the effect of corporate governance variables (such as board size, board gender composition, board competency, board experience in the finance sector, 
meeting frequency of , size of audit committee, CEO duality, and CEO gender) on MFIs performance. The study used descriptive statistics, correlation and panel data regression methods (fixed effect model). Unlike Eyob (2016), this study found that board size, board competency, board experience and meeting frequency of board has a significant impact on the financial performance of Microfinance Institutions. However, Board gender composition, CEO duality and CEO gender does not have significant impact on the financial performance of Microfinance Institutions.

\subsection{Conceptual Framework}

Based on the reviewed literatures the following conceptual frame work has been constructed

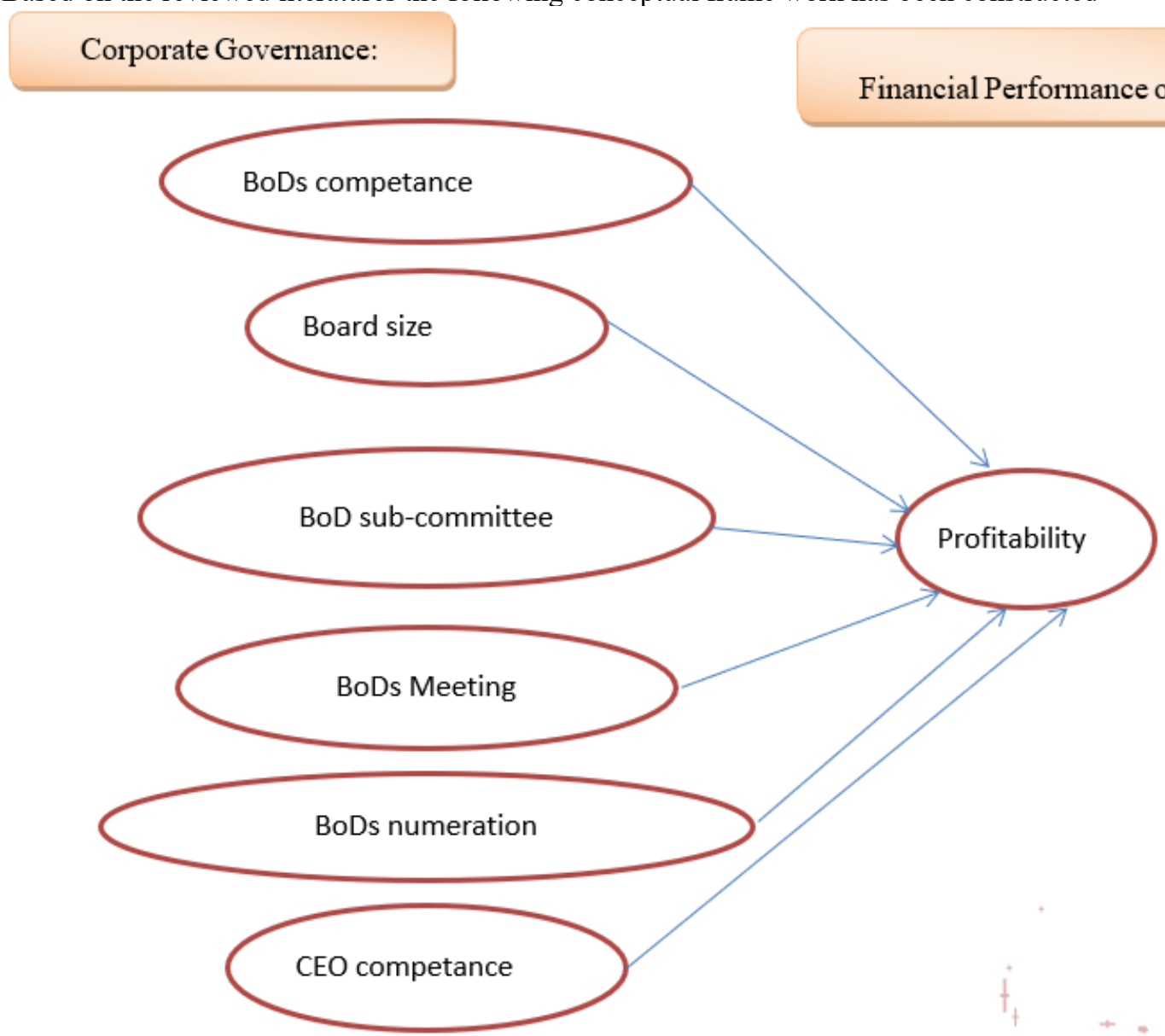

\section{MATERIALS AND METHODS}

To get better insight about the effect of corporate governance on financial performance of MFIs in Ethiopia, quantitative approach with explanatory research design was adopted.

The Population of the study was registered members of Ethiopian Microfinance Institutions (AEMFI) with complete three years data and above. From the total 34 registered members of AEMFIs 25 MFIs with complete three year data was selected for the study. In this study both primary data and secondary data were collected. Primary data was collected by questionnaire. The questionnaire was designed in a way that able capture all corporate governance variables and distributed physically and through email as appropriate to $\mathrm{CEO}$ / or other senior management of each selected MFIs. The secondary data also collected from annul performance analysis report (Bulletin 12 to 14) of Association Ethiopian Microfinance Institutions over period of three years (2017 to 2019).

The data obtained from primary and secondary source was analyzed according to objective of the study. To estimate the effect corporate governance variables under consideration on financial performance (profitability) of MFIs, multiple regression analysis was employed. Duet to combination of cross sectional and time series of the data, fixed effect model was employed using Statistical Packages for Social Science (SPSS). Panel data involves the pooling of observations on a cross-section of units over time periods and provides results that are simply not detectable in pure cross-sections or pure time-series studies (Freeman 1984) as cited by Bonsa (2015).

Descriptive analysis was also employed to describe the important features of variables under study. To identify the relationship between dependent, independent variables correlation analysis was also conducted. 
The following panel regression model was adopted for the study:

$\mathrm{Y}_{i t}=\alpha_{\mathrm{it}}+\sum \beta \mathrm{X}_{\mathrm{it}}+\varepsilon_{\mathrm{it}}$

Where:

$\mathrm{Y}_{i t}$ dependent variables represent RoA

$\alpha$ intercept

$\beta$ slope coefficient of explanatory variables

$\mathrm{X}_{i t}$ set of explanatory variables in the model represents corporate governance variable under study such as board size, board subcommittee, boards educational qualification, boards industry specific experience, numeration, board meeting frequency, CEO educational qualification, CEO industry experience.

Where subscript $i$ and $t$ denote the individual institutions characteristics (cross sectional dimension) and time series dimension respectively.

\section{RESULTS AND DISCUSSION}

\subsection{Descriptive Statistics Result}

Based on the objective of the study, corporate governance variables and financial performance data of 25 MFIs over three years period was taken to analysis their causal relationship. The result showed that average member size of board of directors is 6.5 and ranges from 5 to 12. This result is the bellow recommendation of Council of Microfinance Equity Funds which is 7 to 9 (Chenuos et al, 2014). According to Parthasarathy et al (2019), a MFI's board member size need to be large enough to incorporate required skills and different views, and still small enough to allow active participation of all members and easy arrangement of meetings. Currently, the minimum size of board members allowed for MFIs in Ethiopia is five.

The data about number of sub-committees with in the main board showed that sub-committee established with in MFIs board ranges from zero to 3 and the average is 1.88 (see table 1). As indicated table 2, 24\% of MFIs included in the study has no committee established with in the main board while the reaming $76 \%$ have at least one sub-committee. According to Parthasarathy et al (2019), board committees can reduce the amount of time all boards spend in deliberations and results in reduction of superficial decision making by the boards if used effectively. The same study indicated the importance of risk committee, audit committee, asset liability committee and human resource committees for MFIs' board decision making. As shown in table 2, from the total MFIs included in this study $72 \%$ have two or three committees that monitor the MFIs, and provide advice and information for main boards to facilitated informed and effective decision making.

It can also be observed from the result that allowance or numeration for the individual board members ranges from zero to ETB 120,000 per annum and the average is ETB 26, 618.67.

Average adjusted ROA of the 25 MFIs is $0.0683(6.83 \%)$ over three years period and ranges from -0.39($39 \%)$ to $0.33(33 \%)$ with standard deviation of 0.10754 . The result also shows that on average 2.59 of board members are post graduate holders. Comparing this figure with average board size, the proportion of board members having post graduate degree holders is $39.78 \%$ (see table 2). Concerning educational qualification of the MFIs' CEOs, $60 \%$ of CEOs have master's degree whereas the remaining $40 \%$ have first degree (table 3 ). Similarly $78.7 \%$ of CEOs has more than 10 years of industry experience while $21.3 \%$ have six to ten years of industry related experience (table 4). The results of both education level and industry specific experience of CEOs reveals that CEO competence is far above minimum requirements set by regulatory body.

According NBE directive No. MFI/21/12, the minimum requirement need to be fulfilled by a Chief Executive Officer of MFIs is first degree and 5 years of industry experience, of which three years is management position.

Association of Ethiopian MFIs has reported categorized scale of MFIs as small, medium and large based on loan portfolio. Accordingly, majority of MFIs are those in large category. As shown in the table 5 below, $60 \%$, $28 \%$ and $12 \%$ of MFIs included in this study are in large, medium and small category respectively.

\subsection{Correlation Analysis}

Under this section the result of Pearson Correlation analysis is presented. By using Pearson Correlation the relationship between corporate governance variables and financial performances (measured in ROA) of MFIs under study was analyzed. Although it does not indicate causal effect, correlation analysis shows the degree and direction of relationship between dependent variable and independent variables.

As shown in table 5, the relation of board size and CEO industry experience with RoA is positive at $5 \%$ significance level. Likewise RoA of MFIs under the study is positively related with board sub-committee, board of directors' numeration, educational qualification of boards of directors, education level CEO and scale of MFIs at $1 \%$ of significance level.

According to Hair et al. (2010) as cited by Abel (2019), relationship is considered small when correlation coefficient is ranges between plus/or minus $( \pm) 0.1$ to \pm 0.29 , while the relationship is considered to be medium when it is between \pm 0.30 to \pm 0.49 , and strong when it is above equal to \pm 0.50 and above. Based on this 
suggestion, relation of board size and CEO industry experience with ROA of MFIs under consideration is weak, whereas the relationship of board subcommittee, board educational qualification, MFIs scale (the control variable) and $\mathrm{CEO}$ education with ROA medium. Interestingly, the relationship between board allowance (numeration) and profitability of MFIs measured in ROA is strong.

To conclude the section, the correlation analysis reveals there is a relation between corporate governance variables and profitability of MFIs measured in return on asset. However it is not possible to predict the causal inferences using this analysis alone. Therefore, regression model analysis is presented in the next section to identify the causal effect of corporate governance variables on financial performance of MFIs in Ethiopia as the objective of the research project.

\subsection{Regression Analysis}

Before jumping to running regression analysis, explanatory variables identified for the study were tested whether there is serious multicollinerity problem among them or not. Accordingly variable inflated factor (VIF) were computed to check multicollinerity among variables, The VIF values shown in appendix 2 indicate that the explanatory variables included in the regression analysis have no multicollinearity problem. It is far below the tolerance level which is 10 .

As specified on the preceding chapter, fixed factor effect model is used to analyze the effect of corporate governance on the financial performance of MFIs. The regression result is found from SPSS 26.

The regression result reveals that the overall model is significant at $1 \%$ level that suggests the corporate variables included in the analysis are statistically significant in jointly explaining the financial performance (ROA) of MFIs in Ethiopia. Likewise as shown in result table, the adjusted R square is 0.504 reveals that $50.4 \%$ of financial performance of MFIs in Ethiopia is explained by corporate governance practice included in the study such as board size, number board sub-committee, education qualification of board members, numeration for boards of directors, competence of MFIs' CEO jointly, while the remaining $49.6 \%$ of financial performance is explained by other factors (see table 7). The effect of individual variables under the study on ROA is presented below.

Board size (BoDSize): The effect of board members size on financial performance is positive as we expected by but not significant. Belete (2015), who has conducted study in the topic found positive and significant effect of board size on financial performance of MFIs in Ethiopia. Unlike this finding, Eyob (2016) has found negative and significant effect of board size on financial performance of MFIs.

Board sub-committee (SubCom): The effect of number sub-committee established in the main board is found to be unexpectedly negative but statically insignificant at conventional level.

Numeration (NumerationN): The effect of numeration on financial performance of MFIs in Ethiopia is positive and statically significant at 5\% level. This result reveals that an increase in board bombers' allowance increases their commitment of supervision and supports that result in financial performance MFIs. This may because as most of MFIs in Ethiopia are regional governments and NGOs backed where board members are not real shareholders that personally benefit from profitability of the institutions except the numeration. As of the researcher's knowledge, there were no prior researchers that considered this explanatory variable in their analysis.

Educational qualification of board of directors (BoDEduM): The effect of number of board of directors with post graduate degree on ROA of MFIs as expected by the researcher but statically insignificant.

CEO educational (CEOEduN): Another interesting finding of this research is that the effect of level education of a Chief Executive Officer on MFIs' financial performance is positive and significant at the 5\% level. This reveals that the higher educational qualification of a CEO, the better is the financial performance of a particular MFI if other variables remain constant.

CEO industry experience (CEOIndExpN): As we expect the effect of industry related experience of CEO has positive effect on financial performance of MFIs. The result is, however, statistically insignificant.

MFI Scale (MFIScaleN): It is used as control variable for the study. Result of the regression reaves that the effect of MFI on financial performance is positive and significant. This suggests the larger the MFIs, the better in financial performance of MFIs. This can be because of economies of scale advantage.

4. Conclusion

The descriptive statics result showed that average member size of board of directors is 6.5 and ranges from 5 to 12, which is bellow recommendation of Council of Microfinance Equity Funds. The result also shows that the proportion of board members having post graduate degree holders is $39.78 \%$ on average. Board sub-committee established with in the main board ranges from 0 to 3 and the average is 1.88 . Out of total MFIs included in the study $24 \%$ has no committee established with in the main board while the reaming $76 \%$ have at least one subcommittee. The result also shows that average numeration of board of directors is ETB 26, 618.67 per year and ranges from 0 to ETB 120,000.

The result on educational qualification of the MFIs' CEOs shows that $40 \%$ have master's degree whereas 
the remaining $40 \%$ have first degree. Similarly, $78.7 \%$ of CEOs has more than 10 years of industry experience while $21.3 \%$ have six to ten years of industry related experience.

Concerning the scale of MFIs considered in the study, $60 \%$ are in large category while $28 \%$ and $12 \%$ are in small and medium category respectively.

Average adjusted ROA of the MFIs included in the study is $6.83 \%$ and ranges from $-39 \%$ ) to $33 \%$ with standard deviation of 0.10754 .

According to the correlation analysis result, the relation of board size and CEO industry experience with RoA is positive at 5\% significance level. Likewise board sub-committee, board of directors' numeration, educational qualification of boards of directors, education level CEO and scale of MFIs are also positively related with ROA at $1 \%$ of significance level. Based on suggestion by Hair et al. (2010), the relationships between boards allowance (numeration) and ROA, is strong whereas the relation of board subcommittee, board educational qualification, MFIs scale and CEO education with ROA is medium. The relation of the remaining two variables (board size and CEO industry experience) with ROA is weak.

The result of regression analysis conducted also shows that the overall model employed is significant at $1 \%$ level that suggests the corporate variables included in the analysis are significant in jointly explaining the financial performance (ROA) of MFIs in Ethiopia. Likewise, the adjusted R square result shows that 50.4\% of financial performance of MFIs in Ethiopia is explained by corporate governance practices included in the study such as board size, number board sub-committee, education qualification of board members, boards numeration and competence of CEOs jointly. Out of seven explanatory variables identified for the study three are found significant and affect the dependent variable in expected direction.

The effect of boards' numeration, CEO education level and MFIs scale on financial performance MFIs in Ethiopia is positive and significant at $5 \%, 5 \%$ and $1 \%$ respectively. Whereas the effect board size, educational qualification of boards of directors and industry experience of CEO is positive as expected by the researcher but found insignificant. Unlike these, the effect of number of subcommittee on ROA is unexpectedly negative though it is not significant.

On the bases of these finding, which is aligned with the research project objectives it possible to conclude that improving corporate governance practices of MFIs such as appropriate number of qualified board members, reasonable allowance payment for board of directors, recruiting competent CEO in Ethiopia improves their financial performance and insure sustainability if other factors remain unchanged.

\section{Implications}

Based on the findings of this research project the researcher recommends the following for policy makers, regulatory body and practitioners of the sector.

Board size and educational qualification has positive effect on financial performance of MFIs in Ethiopia but the influence is not significant. This implies that the concerned body not only need give due attention for optimum number and qualification of board members but also rethinking on how to enable optimum commitment and effort of board members. This may include restructuring the ownership of the institutions to fill the board members with real shareholders.

The effect of board numeration on financial performance is found positive and statically significant. It implies that management of MFIs need to give due attention for boards allowance to get required supportive supervision from board members.

Competence of CEO has appositive significant effect on financial performance of MFIs in Ethiopia. Thus, in addition to other qualities, it is important to target educational qualification and industry experience during the recruitment process of CEOs.

\section{REFERENCES}

Abel, H., 2019, "The effect of Corporate Governance Practices on the Financial Performance of Public Enterprises in Ethiopia", A Research Project Submitted In Partial Fulfillment of the Requirements For The Award Of Degree Of Master Of Business Administration in Finance, Addis Ababa University

Amha, W., 2012, 'The Development of Deposit- taking Microfinance Institutions in Ethiopia: Performance, Growth Challenges and the way forward', Occasional Paper No.32.

Anteneh, K., 2018, Association of Ethiopian Microfinance Institutions Performance Analysis Report, Bulletin 13 Association of Ethiopian Microfinance Institutions, 2016, Performance Analysis Report, Bulletin 12

Belete, Z., 2015, 'The Impact of Corporate Governance on Microfinance Institutions Financial Performance in Ethiopia', A thesis submitted to the department of Accounting and Finance in partial fulfillment of the requirement of Master of Business Administration (MBA) Degree in Finance, Addis Ababa.

Bonsa, M., 2015, 'Impacts of Corporate Governance Mechanism on Financial Performance of Selected Insurers in Ethiopia'. A thesis Presented in Partial Fulfillment of the Requirements for the Degree of Master of Science in Accounting and Finance', Addis Ababa 
Chenuos, NK. , Mohamed, A., \& Bitok, SK., 2014, 'Effects of Corporate Governance on Micro Finance Institutions Financial Sustainability in Kenya', European Journal of Business and Management, Vol.6, No.30, 2014, ISSN 2222-1905 (Paper) ISSN 2222-2839 (Online)

Christen, R.P. \& Drake, D., 2001, 'Commercialization of Microfinance. Working Study, Microenterprise Best practices (MBP), Development Alternatives', Inc., USAID project, Bethesda

Creswell, J., 2008, 'Educational research: Planning, conducting, and evaluating quantitative and qualitative research'. New Jersey: Pearson: Merrill Prentice Hall.

Donaldson, J., \& Fafaliou, I. 2003, 'Business ethics, corporate social responsibility and corporate governance: a review and summary critique', European Research Studies Journal, 6(1-2), 90-110.

Eyob, M., 2016, 'Effects of Corporate Governance on the financial performance of Micro-Finance Institutions in Ethiopia' A Thesis submitted to Addis Ababa University in Partial Fulfillment of the Requirements for the Degree of Masters in Accounting and Finance, Addis Ababa.

Ferreira, D., 2010, 'Board Diversity', Journal of Corporate governance: A synthesis of theory, research, and practice', John Wiley \& Sons

Gustave, T., 2012, Corporate Governance and Performance of Microfinance Institutions: A Case Study Of Rwandaa Thesis Submitted In Fulfilment Of The Requirements For The Degree of Doctor of Philosophy In Business Management of The Open University Of Tanzania

Habbash, M. 2010, 'The effectiveness of corporate governance and external audit on Constraining earnings management practice in the UK', Doctoral thesis, Durham University.

Hickman, 1992, 'The Role of outside Directors in Bank Acquisitions', Journal of Financial Management, Vol.26, No. 3, Willey

Hutchison, M., 2002 'Analysis of the association between firms, Investment opportunities, Board composition and Firm performance', Asia Pacific journal of Accounting and Economics, vol. 9: pp 18-40.

Hulme, D., and Mosley P., 1996, Finance Against Poverty, Vol. 1, London: Routledge

Ledgerwood, Joanna \& White, 2006, 'Transforming Microfinance Institutions: Providing Full Financial Services to the Poor', World Development Bank

Leila Mokkadem 2009 Concept Note on Microfinance Scaling Up in Africa: Challenges Ahead and Way Forward, African Development Bank.

Léopold, D., Isidore, B., Jean-Michel, S., \& Frédéric, T., 2017, 'Governance and Performance of MFIs: The Cameroon Case', Journal of Management and Governance, DOI 10. 1007/s10997-017-9381-9

Mersland, R., \& Strom, R., 2007,'Performance and corporate governance in Microfinance institutions', MPRA paper 3887, Agder University. Online at https://mpra.ub.uni-muenchen.de/3887

Meyer, R.L. 2002. Track record of financial institutions in assisting the poor in Asia ADB Institute Research Paper. N.4. December 2002.

National Bank of Ethiopia, 2019, Corporate Governance Framework for MFIs in Ethiopia, Addis Ababa, unpublished report

National Bank of Ethiopia, 2012, Requirements for Person with significant influence in MFI Directive No. $\mathrm{MFI} / 21 / 2012$

Robert C., and Jonathan M., 2017, Microfinance and Economic Development, Policy Research Working Paper, World Bank Group

Robinson, M., 2001, 'The Microfinance Revolution: Sustainability Banking for the Poor', Washington, DC: The World Bank and Open Society Institute.

Rock, R., Otero, M. \& Saltzman, S., 1998, 'Principles and practices of Microfinance Governance', Microenterprise Best Practices Project of the U.S. Agency for International. Financial performance in Nigeria, Final report presented to the Biannual Research Workshop of the AERC, Nairobi, Kenya.

Tadele Getahun, 2017, 'The Effect of Corporate Governance on the Performance of Private Commercial Banks in Ethiopia' a thesis submitted to Presented in Partial Fulfillment of the Requirements for the Degree of Masters of Business Administration in Financial Management

Teshome, K., Anteneh, K., 2020, Association of Ethiopian Microfinance Institutions Performance Analysis Report, Bulletin 14

Thi Dieu, T., Van D. \& Manh D., 2002, 'Financial Performance and Corporate Governance in Microfinance: Evidence from Vietnam', European Journal of Business and Management, Vol.12, No.3, 2020, ISSN $2222-$ 1905 (Paper) ISSN 2222-2839 (Online)

Yenesew Ferede 2012; The Impact of Corporate Governance Mechanisms on Firm's Financial Performance: Evidence from Commercial Banks in Ethiopia; A Thesis Submitted to The Department of Accounting and Finance Presented in Partial Fulfillment of the Requirements for the Degree of Master of Business Administration in Finance 
Table 1. Board size, Board sub-committee, board members education, numeration and ROA of sampled MFIs

\begin{tabular}{|c|c|c|c|c|c|}
\hline Variables & Obs & Minimum & Maximum & Mean & $\begin{array}{l}\text { Std. } \\
\text { Deviation }\end{array}$ \\
\hline Board Size, number & 75 & 5 & 12 & 6.51 & 1.597 \\
\hline Board Sub-committee, number & 75 & 0 & 3 & 1.88 & 1.185 \\
\hline $\begin{array}{l}\text { Board members educational qualification, } \\
\text { number }\end{array}$ & 75 & 0 & 7 & 2.59 & 2.100 \\
\hline Numeration per year, ETB & 75 & 0 & 120000 & 26618.67 & 26664.871 \\
\hline ROA, ratio & 75 & -.39 & .33 & .0683 & .10754 \\
\hline
\end{tabular}

Source: study result

Table 2. Sub-committees established in sampled MFIs

\begin{tabular}{lccc}
\hline $\begin{array}{l}\text { Number of sub-committee } \\
\text { established }\end{array}$ & Frequency & Percent & Cumulative Percent \\
\hline 0 & 18 & 24.0 & 24.0 \\
1 & 3 & 4.0 & 28.0 \\
2 & 24 & 32.0 & 60.0 \\
3 & 30 & 40.0 & 100.0 \\
Total & $\mathbf{7 5}$ & $\mathbf{1 0 0 . 0}$ & \\
\hline
\end{tabular}

Source: study result

Table 3. CEO educational qualifications

\begin{tabular}{ll}
\hline CEO education level & Percent \\
\hline First degree & 40 \\
Master's degree & 60 \\
Total & $\mathbf{1 0 0}$ \\
\hline
\end{tabular}

Source: Study result

Table 4: CEO industry experience

\begin{tabular}{ll}
\hline CEO industry experience & Percent \\
\hline Above ten years & 78.7 \\
Six to ten years & 21.3 \\
Total & $\mathbf{1 0 0}$ \\
\hline
\end{tabular}

Source: study result

Table5: MFI classification by scale

\begin{tabular}{lcc}
\hline Scale & Percent & Cumulative Percent \\
\hline Large & 60 & 60 \\
Medium & 28 & 88 \\
Small & 12 & 100 \\
Total & & \\
\hline
\end{tabular}

Table 6: Correlation coefficient

\begin{tabular}{lc}
\hline Variables & ROA \\
\hline ROA & 1 \\
BoDSize & $.281^{*}$ \\
SubCom & $.338^{* *}$ \\
NumerationLN & $.534^{* *}$ \\
BoDEducM & $.412^{* *}$ \\
CEOEduN & $.349^{* *}$ \\
CEOIndExpN & $.232^{*}$ \\
MFIScaleN & $.418^{* *}$ \\
\hline$* *$ Correlation is significant at the 0.01 level (2-tailed). * Correlation is significant at the 0.05 level (2-tailed).
\end{tabular}


Table7: Fixed effect regression result

Coefficients $^{\mathbf{a}}$

\begin{tabular}{|c|c|c|c|c|c|}
\hline \multirow[b]{2}{*}{ Model } & \multicolumn{2}{|c|}{ Unstandardized Coefficients } & \multirow{2}{*}{$\begin{array}{c}\text { Standardized Coefficients } \\
\text { Beta } \\
\end{array}$} & \multirow[b]{2}{*}{$t$} & \multirow[b]{2}{*}{ Sig. } \\
\hline & $\mathrm{B}$ & Std. Error & & & \\
\hline 1 (Constant) & -.641 & .151 & & -4.258 & .000 \\
\hline Year2 & .062 & .022 & .269 & 2.772 & .007 \\
\hline Year3 & .085 & .023 & .367 & 3.727 & .000 \\
\hline BoDSize & .008 & .008 & .113 & .990 & .326 \\
\hline SubCom & -.008 & .014 & -.089 & -.587 & .559 \\
\hline NumerationLN & .031 & .015 & .258 & 2.005 & .049 \\
\hline BoDEducM & .006 & .007 & .116 & .937 & .353 \\
\hline CEOEduN & .071 & .028 & .319 & 2.488 & .016 \\
\hline CEOIndExpN & .026 & .024 & .099 & 1.079 & .285 \\
\hline MFIScaleN & .051 & .015 & .332 & 3.317 & .002 \\
\hline
\end{tabular}

a. Dependent Variable: ROA

\begin{tabular}{|c|c|c|c|c|c|c|c|}
\hline \multicolumn{8}{|c|}{ Model Summary } \\
\hline 1 & $.753^{\mathrm{a}}$ & .566 & & & .504 & & .07726 \\
\hline \multicolumn{8}{|c|}{$\begin{array}{l}\text { a. Predictors: (Constant), MFIScaleN, Year3, SubCom, CEOIndExpN, Year2, BoDSize, BoDEducM, } \\
\text { CEOEduN, NumerationLN }\end{array}$} \\
\hline \multicolumn{8}{|c|}{ ANOVA $^{\mathrm{a}}$} \\
\hline Model & & Sum of Sg & & df & Mean Square & $\mathrm{F}$ & Sig. \\
\hline \multirow[t]{3}{*}{1} & Regression & & .484 & 9 & .054 & 9.002 & $.000^{\mathrm{b}}$ \\
\hline & Residual & & .370 & 62 & .006 & & \\
\hline & Total & & .854 & 71 & & & \\
\hline
\end{tabular}

a. Dependent Variable: ROA

b. Predictors: (Constant), MFIScaleN, Year3, SubCom, CEOIndExpN, Year2, BoDSize, BoDEducM, CEOEduN, NumerationLN 